\title{
Indian Electricity System Transition and Its Challenges: A Review
}

\author{
S. BALASUBRAMANIAN ${ }^{*}$ AND P. BALACHANDRA \\ Department of Management Studies, Indian Institute of Science, Bengaluru, India
}

\begin{abstract}
Climate change concerns, resource constraints on conventional energy sources, everincreasing electricity demand with new loads on the consumer side, improving electricity access, and the new challenge of matching dynamic energy resources with dynamic demand have forced the transitions in electricity systems worldwide. The Indian electricity system is undergoing significant transitions concerning all segments, viz., electricity generation, transmission \& distribution, and demand-side to manage such challenges. These transitions throw numerous challenges in technical, economic, social, and policy dimensions. This paper tries to elucidate these transitions and associated challenges in the Indian electricity system. The overall goal of the paper is to present such an understanding of these transitions to introduce appropriate interventions for the effective operation of future electricity systems. The electricity sector has a cardinal role in reducing global greenhouse gas emissions. Only a sustainable electricity system can cater to the needs of the people. It can be concluded that the electricity sector's transition is inevitable, and it is eternal.
\end{abstract}

Keywords: electricity, India, transitions, challenges

\section{INTRODUCTION}

Electricity plays a critical role in fulfilling essential needs of people like access to clean water, increased agricultural productivity, health care, education, employment, and better lifestyles. Thus, the electricity demand is growing rapidly not only to meet the above essential needs but also to the advent of modern technologies, industrialization, and growing aspirations for economic prosperity. Due to their lifestyle changes, the burgeoning exigency of people's electricity demand has entrusted the electricity system with enormous pressure for more electricity generation. Both production and consumption of electricity have significant challenges that need to be addressed and resolved by the nations both in the developing and developed world to ensure continuity of human prosperity and ecological sustainability [1]. Being the laggards in the development process, the developing countries, especially countries of the African and South Asian regions, are expected to be severely impacted by these challenges. The most significant challenges are: (i) growing demand for electricity and high dependency on constrained and non-renewable energy resources. The constrained conventional electricity generation sources/technologies, even though ensure

\footnotetext{
*Corresponding author: balasubramaniansa@gmail.com

Received: 4 Dec 2021 Accepted: 6 Jan 2022 Published: 17 Jan 2022

Journal of Asian Energy Studies (2022), Vol 6, 1-24, doi:10.24112/jaes.060001
} 
surety and reliability of supply to meet the dynamic electricity demand but disembark from global electricity system targets to reduce GHG emissions [2]; (ii) A large section of the population is still deprived of access to electricity, i.e., around one billion people (which is close to $13 \%$ of the World population) lack electricity access [3]. The countries with the most extensive electricity deficit are concentrated in South Asia and Sub-Saharan Africa. If the current policy regime continues, it is predicted that 674 million people will still lack access to any form of electricity by 2030, which is the target year to achieve $100 \%$ global electrification [3]. Income poverty is one of the most important reasons for the lack of electricity access [4]; (iii) fossil fuel dependency for power generation contributes to growing GHG emissions. For example, the global carbon dioxide $(\mathrm{CO} 2)$ emissions of 33,444 million tonnes in 2017 is a $1.6 \%$ increase from the 2016 estimate [5]. The corresponding number for 2007 is 30,079 million tonnes of CO2. On average, the CO2 emissions are growing at a rate of $1.3 \%$ per annum in the last decade [5].

The installed electricity system capacity of most countries in the World is fossil fuel dominated with little contribution from renewable energy sources (RES) [6]. But due to the fossil fuelinduced greenhouse gas emissions, resource constraints on conventional energy sources, everincreasing electricity demand associated with new loads on the consumer side, duty-bound to improve electricity access has forced countries to add renewable energy into the electricity system capacity [7]. This shift from no/minor renewable contribution to minor/substantial renewable contribution in the installed electricity system capacity is termed as "Transitions" [8-10]. The requisite of the developed country is to replace the existing conventional capacity with renewable energy resources while assuring the security of supply to comply with the global emission norms [11]. At the same time, the developing and underdeveloped countries are tasked to ensure the transitions to supply reliable electricity to all the population [12]. Following the above, transitions are emerging viz., transitions in the generation side, transmission \& distribution side, and in the demand side ambits of the electricity system [13]. Several vital challenges arise from these impending electricity system transitions [14]. These transitions and their challenges have to be understood and dealt with appropriately else it results in the possible malfunctioning of the electricity system $[15,16]$. The transition in the electricity sector is inevitable, and the challenges arising out of this transition are inexorable [17].

This paper aims to study the need for transitions and the associated challenges in the electricity system, taking India as an example with the help of literature. As a developing country, India is becoming a global superpower facing all the above challenges. Moreover, the Indian electricity system is undergoing energy transitions by adding substantial renewable energy-based capacity to its installed electricity capacity portfolio [18-20]. Since the Indian electricity system is large, complex to manage and the demand to be met is very high and dynamic, matching the supply and demand with variability and intermittency in generation poses an ominous challenge to the electricity system planners. In this context, this study is essential as its objective is to investigate the need for transitions in the Indian electricity sector and discuss the challenges arising out of these transitions in all spheres of the electricity system. Understanding these transitions and the future challenges is imperative for exploring/initiating necessary technical and policy interventions. To the best of our knowledge, there is no previous study that provides a detailed and systematic synthesis of transitions and the associated challenges in the Indian electricity system.

This paper is structured as follows. Section 2 lists the various factors that initiate the transitions into the Indian electricity system. Section 3 dissects the emerging transitions in the generation, transmission \& distribution, and demand-side spectrum of the system. Section 4 presents the various challenges arising out of the transitions and their potential implications. Section 5 concludes. 


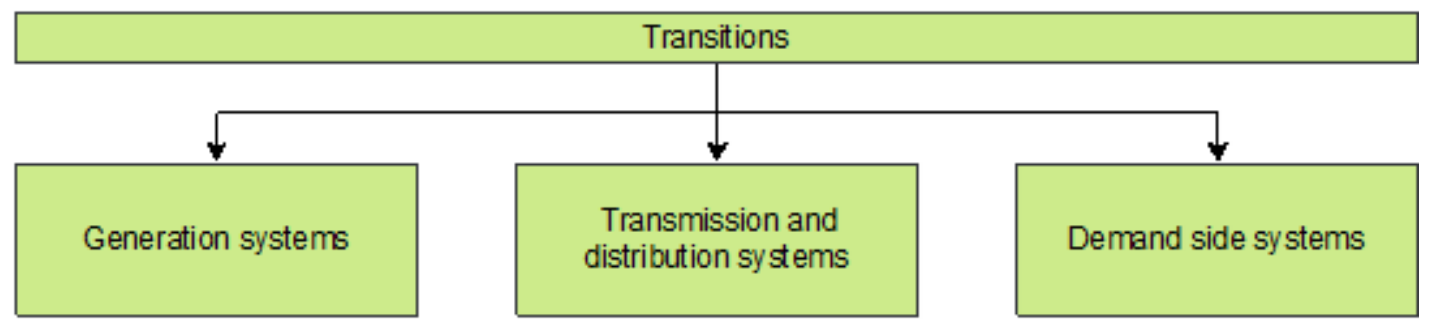

Figure 1: Transitions in the Indian electricity sector

\section{EMERGING TRANSITIONS IN THE INDIAN ELECTRICITY SYSTEM}

The transitions eventuating in the electricity sector (Fig. 1) are clustered as Transitions in generation systems, transmission and distribution systems, and demand-side systems.

\subsection{Transitions: Generation Systems}

The transitions in the electricity generation systems can be grouped into the alteration in the system portfolio, changes in conventional generation technologies, changes in methods of electricity generation, and changes in ownership structure.

\subsubsection{Alternation in electricity system portfolio}

The evolution of the electricity generation in India through different sources is shown in Fig. 2. The earliest technology employed for electricity generation is hydropower in 1897 [73]. It was followed by the commissioning of the first thermal (coal) power plant in the year 1920 [74]. Till Independence, the progress in the Indian electricity sector is very low. The contribution of different sources to India's installed capacity is given in Fig. 3. In 1947 all India installed capacity was just $1.3 \mathrm{GW}$ constituting only coal $(0.75 \mathrm{GW})$, hydropower $(0.50 \mathrm{GW})$, and diesel $0.098 \mathrm{GW}$. During the initial years, the installed electricity capacity was dominated with major contributions from large hydro and thermal power [23]. Due to India's abundant coal reserves, the target was to construct large coal power plants to electrify different parts of the country $[75,76]$. So, the erstwhile five-year plans concentrated on building large coal thermal power plants. Besides, as India was an agricultural country, large dams were common, including hydropower projects [77]. This trend continued until 1980 when coal and large hydro contributed 16 GW (share 56\%) and 11 GW (share $40 \%$ ) respectively to installed capacity. However, post that the share of large hydro has reduced owing to the problems associated with its construction [78]. From 1980 country's policy emphasized adding more coal power plants. As of 2020, the installed capacity of coal and large hydro is $206 \mathrm{GW}$ (share 55\%) and $46 \mathrm{GW}$ (share 12\%), respectively. In the last 15 years installed capacity of large hydro has increased by just 32\%, whereas the corresponding increase in coal is $190 \%$. The contribution of coal was as high as $60 \%$ in 2017 . Though its installed capacity is increasing, with the rapid addition of renewable energy sources, the coal contribution is decreasing in recent years. This trend is expected to continue as India has no plans to add new coal power plants between 2022 and 2027.

During the 1950's several researchers pointed out Nuclear power can satisfy the World's electricity needs [79]. Indian nuclear research program was started in the 1950s, and the first nuclear power plant was commissioned in 1969 [80]. The installed capacity of Nuclear in 1980 was $0.64 \mathrm{GW}$ (share $2 \%$ ), and it had increased to $6.7 \mathrm{GW}$ in 2020 (share $2 \%$ ). The nuclear power plant 


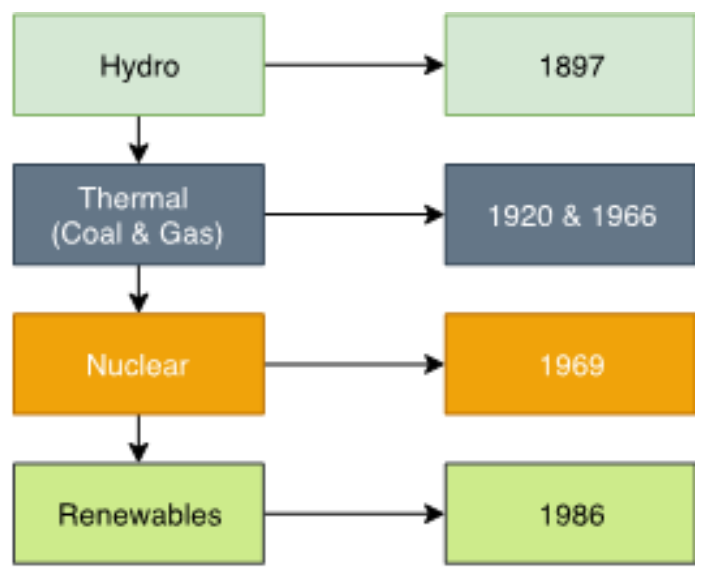

Figure 2: Evolution in the sources of electricity generation

is considered an integral part of the Indian electricity system and is expected to supply substantial quantities in the coming years [81]. Gas contributed as high as 9\% in 2012 and had reduced to $7 \%$, as of 2020. Diesel power $(<1 \%)$ generation plays a minor role in the Indian electricity system mix [29] since $95 \%$ of diesel used in India is imported [82]. The price fluctuations of diesel play a significant role in policy decisions of electricity generation through oil [83]. It can be inferred from Fig. 3 that, till 1986, renewable energy generation was non-existent in the Indian electricity system [35]. In 1992 the installed capacity of renewable energy sources was just $0.032 \mathrm{GW}$ (share $0.046 \%$ ), and it has increased to $91.1 \mathrm{GW}$ (share 24\%) in 2020 [21]. Solar and wind energy are the major renewable energy resources, and both have seen a tremendous increase in the last decade. In 2010 the installed solar capacity was $0.015 \mathrm{GW}$, and it increased to $37.46 \mathrm{GW}$ in 2020. In the same period, the wind has grown from $11.8 \mathrm{GW}$ to $38.62 \mathrm{GW}$. India is also focussing on the installation of small hydro ( $<25 \mathrm{MW})$ systems which are considered essential to the system portfolio [23].

So, India's electricity system is shifting from large centralized to small distributed power generation [84]. Renewable energy will be the major player in the coming years [85]. So, as we can observe that, the target of the electricity system is changing from large hydro and thermal dominated to thermal and renewable energy dominated system. The major factors attributed to this shift are, with large hydro viz., alteration of river direction, harm to the aquatic system, to name a few [86]. Concerning coal, the availability of requisite resources and its ability to supply base load power takes pre-eminence [87]. The climate change concerns and the related $\mathrm{CO} 2$ emissions urge the need for renewable energy sources [88]. So, to supply the increasing demand for electricity with stable and reliable supply sources and reduce carbon emissions, the thermal renewable energy combination is the way forward.

\subsubsection{Changes in conventional generation technologies}

Electricity generation technologies play an important role in decarbonizing the electricity system. Even though renewable energy sources are expected to provide the green push for India's electricity generation mix, but the real gamechanger lies in employing advanced technologies in the Indian coal plants to reduce $\mathrm{CO} 2$ emissions [89]. Coal has been the preferred electricity generation in India as of today, the reason being abundant available coal reserves [90]. However, the calorific value of Indian coal is 30\% to 35\% lower when compared to the rest of the World and has a very high ash content of $25 \%$ to $45 \%$. All the coal power plants in India are pit head, built near 


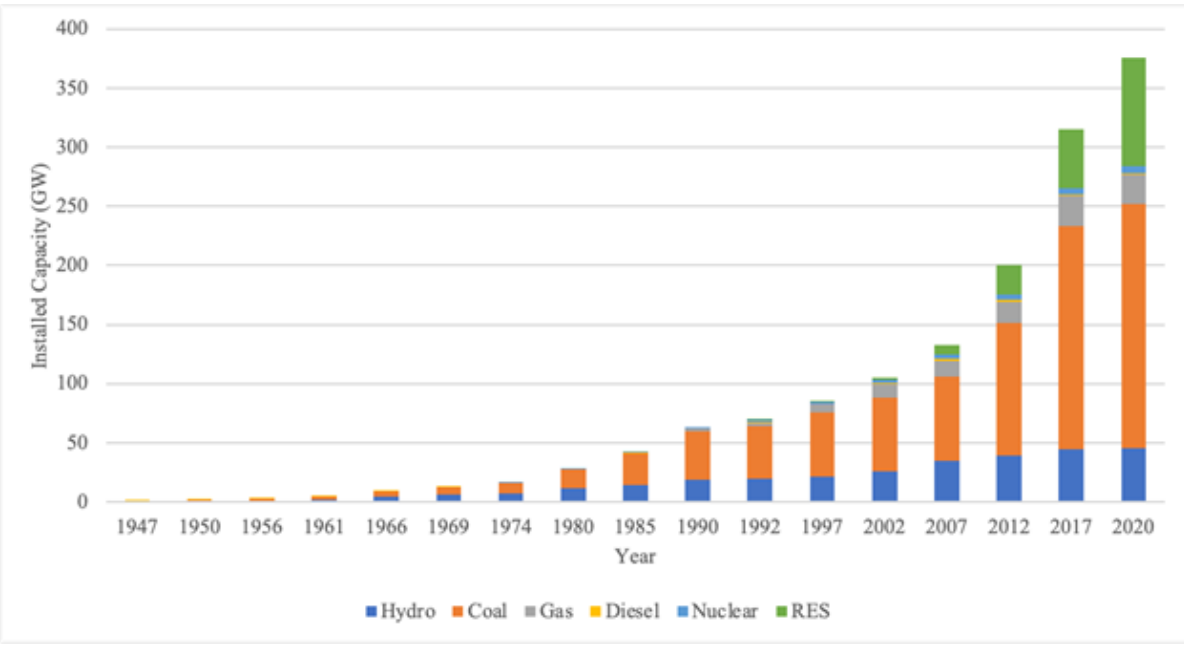

Figure 3: Contribution of different resources to Indian electricity system over the years [35]

the resource base with sub-critical pulverized coal (PC) technology [91]. The efficiency of the technology is low, with $32.53 \%$ in 2009-10, and it also consumes more coal [92]. So India is moving towards super-critical technology, which is $2 \%$ more efficient than sub-critical technology with less emissions [93,94]. At present, all new coal power plants with a unit size of more than $660 \mathrm{MW}$ are based on super-critical technology amounting to $42 \%$ new installations in the 12th plan (2012-2017) period [92]. Between 2017-22 all the new thermal capacities are mainly through super-critical technology. More efficient ultra-super-critical technology is also in the introduction stages in the country.

India has 22 nuclear power stations in operation in six states. The three main technologies in operation are Boiling Water Reactor (BWR), Pressurized Heavy Water Reactor (PHWR), and Water Water Energetic Reactor (VVER) [95]. India's first nuclear plant, Tarapur (2 units), is the only BWR in operation in India [95]. Post-1973, after India's first nuclear test United States withdrew from supplying natural uranium to the Tarapur nuclear power plant. So, India was forced to shift towards PHWR. Presently eighteen nuclear power stations in India are working with PHWR reactors. The last two commissioned reactors in Kudankulam (2014 \& 2017) are VVER reactors supported by Russian technology [92]. The reason for this transition from BWR to PHWR to VVER is the availability of unenriched natural uranium and the indigenous PHWR developed in the country. India's future reactors are planned with indigenous PHWR technology developed in India $[55,95]$.

The different large hydro schemes in India are run of river without pondage, run of river with pondage, and pumped storage [96]. Due to various issues associated with run of river schemes in addition to increased storage requirements, the recent focus of hydropower installations has shifted towards pumped storage schemes. Small hydro projects are based on low head/canal fall schemes.

\subsubsection{Changes in methods of electricity generation}

The conventional power plants are built in large centralized locations near the resource base. The size of these power plants ranges from a few $100 \mathrm{MWs}$ to several GWs. The largest conventional power plant in India is the Vindhyachal thermal power station, with a capacity of $4.6 \mathrm{GW}$. With 
renewable energy sources, electricity generation is distributed in various locations, and size range from Watts to a few MWs. India has a target to have $40 \mathrm{GW}$ of solar rooftop capacity by 2022 [97]. In recent years GW scale solar power plants and wind parks are built in a single location. With electricity system transitions, the power plant configuration is shifting from large centralized to small distributed/large centralized plants. This creates issues related to grid integration, transmission and distribution, generation deficiency/surplus, shifting of load peaks, etc. Managing these issues appropriately will play an important role in the effective operation of the electricity system.

\subsubsection{Changes in ownership structure}

The electricity sector in India is under the concurrent list of the Indian constitution, where both central and state governments are allowed to make legislation. Till Independence, the electricity sector was majorly dominated by private players [66]. Post-independence from 1947 to 1990, the electricity generation was owned only by government entities (state \& center) [67]. During this time, the growth in the generation sector was limited. To meet the increasing demand and to ensure reliable electricity supply coupled with constraints in government investment, private participation in generation was authorized in the year 1991 [24]. The transition in the ownership structure is from only private to only public to mixed (both public and private).

With the involvement of the private sector and favorable government policies, the electricity system has undergone rapid transformation in the past three decades [98]. As of 2020 private sector contributes $177 \mathrm{GW}$ (share $47 \%$ ) of installed capacity, followed by the state sector $104 \mathrm{GW}$ (share $28 \%$ ) and central sector $94 \mathrm{GW}$ (share 25\%), respectively. Fig. 4 shows the sector-wise installed capacity portfolio. In most of the technologies, private sector contribution is the highest to the installed capacity. Only in nuclear and hydro, the private sector has not made any major investments. Due to safety regulations and liability issues, private participation in the nuclear sector is not allowed, and this status may not change in the near future [21]. Concerning hydro, water is a highly contentious issue between different states in India, and the bulk of the hydro plants are owned by the state governments [23]. So private participation is not encouraged in the large hydro sector too. Nearly $96 \%$ of renewable energy installations are owned by the private sector. It is seen as a good avenue for investment. So, private sector participation has been a boost to the rapid addition of installed capacity in the conventional sector, and also it gives a major push to achieve India's renewable energy targets [99]. For India to achieve its renewable energy target, private participation is necessary.

\subsection{Transitions: Transmission and Distribution Systems}

Transmission and distribution (T\&D) form an important part of the electricity system. To reduce T\&D and AT\&C losses, several measures have been taken by the government. The earliest reforms are the setting up of regional load dispatch centers (RLDCs) in 1994 [24]. This intervention aided the respective government in identifying the financial losses and electricity deficit regions. Private investment in the sector was allowed in 1998 [71]. To reduce interference by lawmakers, T\&D was made a separate entity through The Electricity Act 2003, and it paved the way for electricity governing through an independent entity. In terms of policy mechanisms, various schemes are introduced to reduce losses and improve the reliability of the power grid. The government of India introduced Ujwal Discom Assurance Yojna (UDAY) to deal with financial inefficiencies of discom's in the country $[55,100]$. After the launch of this scheme, financial losses have been reduced from INR 490,000 million in 2016 to INR 280,000 million in 2019 [69], and billing efficiency has increased 


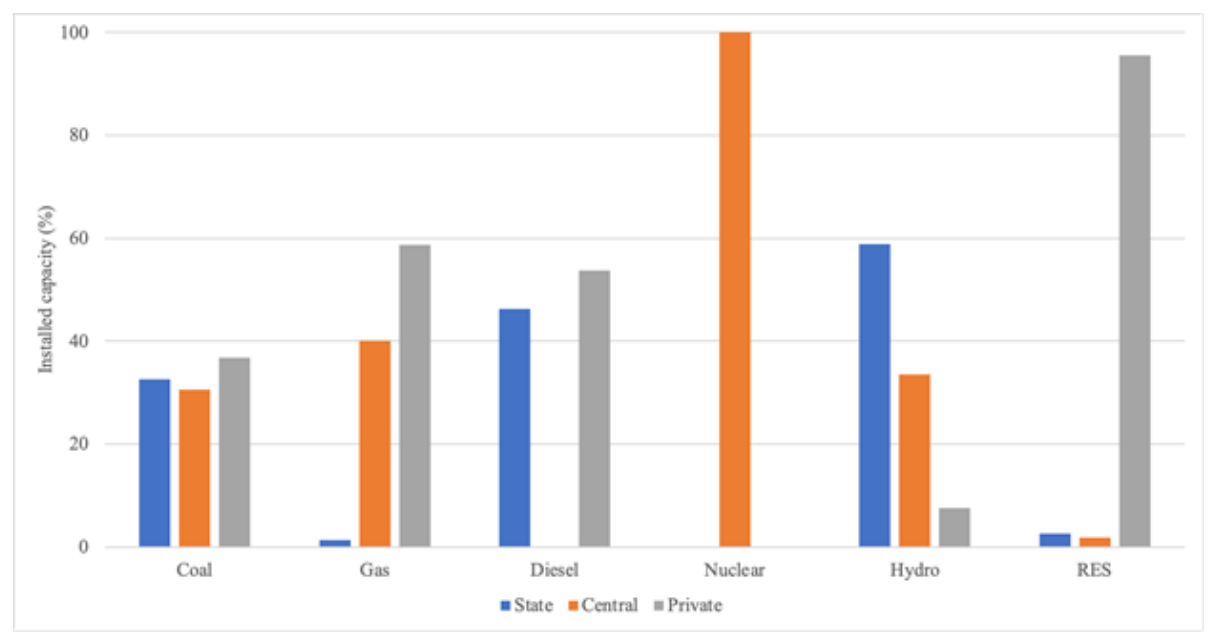

Figure 4: Installed capacity-sector-wise [21]

by $2 \%[71]$.

In the distribution sector, several schemes announced by the government of India are the Integrated power development scheme (IPDS), Deendayal Upadhyaya Gram Jyoti Yojana (DDUGJY), National Smart Grid Mission (NSGM), and National Electricity Fund (NEF). The objective of the IPDS scheme is to strengthen the transmission lines. DDUGJY concentrates on separating agriculture and non-agriculture feeders, the metering of distribution consumers, and rural electrification. With this scheme, the number of hours of electricity supply for households in rural areas has improved considerably. National Electricity Fund (NEF) is an interest subsidy scheme promoted by India's government to increase capital investment in the distribution sector. NSGM was introduced in 2015 to speed up the smart grid development in India [101]. In recent years several measures have been undertaken to improve the electricity infrastructure in the country. Some of the major steps are grid modernization, the introduction of microgrids, replacing electromagnetic meters with smart meters, to name a few. Reducing the losses (technical \& financial) in this sector is crucial to assure reliability in electricity supply and also to improve the financial situation of the discoms.

\subsection{Transitions: Demand-side Systems}

Fig. 5 presents the all-India load curve in 2014 and 2020. It can be observed from the Figure that there is a significant growth in electricity demand and also a considerable change in patterns of electricity consumption. The reasons for these transitions can be attributed to an increase in economic activities, changes in agricultural practices, improvement in living standards, and greater electricity access/electrification [102-104]. In the last decade, several measures have been taken to improve energy efficiency like star-labeled appliances, Bureau of Energy Efficiency (BEE) standards, perform achieve and trade (PAT) cycle, national retailer training program (RTP), etc.

For example, the star-labeled products come with information regarding daily/monthly/annual electricity consumption information. Likewise, the PAT scheme was launched to enhance energy efficiency in energy-intensive industries. Through these, the end-use technologies changed from energy-intensive to energy light. Demand-side management (DSM) is introduced by utilities in different states to induce changes in consumption patterns of consumers' electricity usage and is presented in Table 1. Time of day pricing is the preferred DSM program offered mostly for 
industries and voluntary. All these measures also contributed to reducing India's power and energy shortage over the years.

Table 1: State-level initiatives of DSM in India [105-107]

\begin{tabular}{|c|c|c|c|c|c|}
\hline $\begin{array}{l}\text { Demand-side } \\
\text { management } \\
\text { programs }\end{array}$ & $\begin{array}{l}\text { Time } \\
\text { of day }\end{array}$ & $\begin{array}{l}\text { Power factor } \\
\text { surcharge/ } \\
\text { incentive }\end{array}$ & $\begin{array}{l}\text { Efficient } \\
\text { lighting }\end{array}$ & $\begin{array}{l}\text { Appliance } \\
\text { replacement }\end{array}$ & $\begin{array}{c}\text { Energy audit } \\
\text { programs }\end{array}$ \\
\hline Andhra Pradesh & $x$ & $x$ & $x$ & & \\
\hline Assam & $x$ & & & & \\
\hline Bihar & $\times$ & & & & \\
\hline Chhattisgarh & $x$ & & & & \\
\hline Delhi & $\times$ & $x$ & $x$ & $x$ & \\
\hline Gujarat & $x$ & & & & \\
\hline Haryana & $x$ & & $x$ & & \\
\hline Karnataka & $x$ & & $x$ & $x$ & $x$ \\
\hline Maharashtra & $x$ & $x$ & & $x$ & \\
\hline Tamil Nadu & $\times$ & $x$ & $x$ & & \\
\hline Tripura & $\times$ & & & & \\
\hline Uttarakhand & $x$ & & & & \\
\hline Uttar Pradesh & $x$ & & & & \\
\hline West Bengal & $x$ & & & & \\
\hline
\end{tabular}

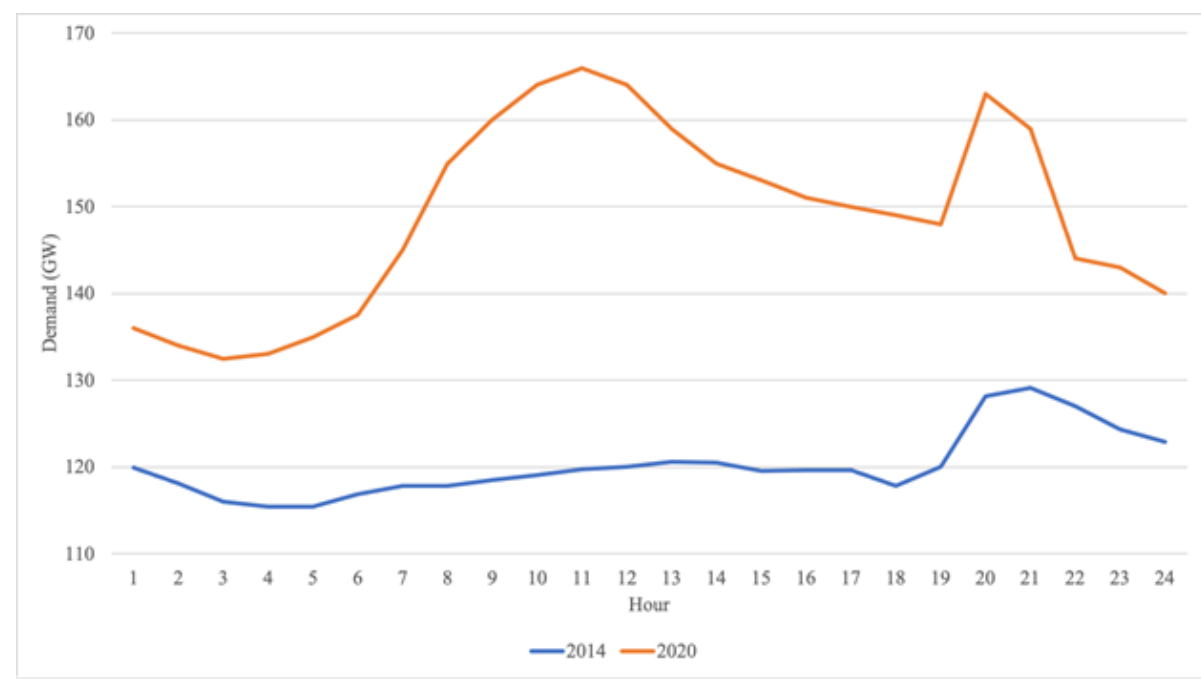

Figure 5: All India load curve on 21st September 2014 and 2020

\section{Electricity System tRANSition: Challenges}

The transition challenges (Fig. 6) are grouped into technical, economic, infrastructure, policy, social and environmental. In this section, we discuss each challenge allied to electricity system transition in detail. 


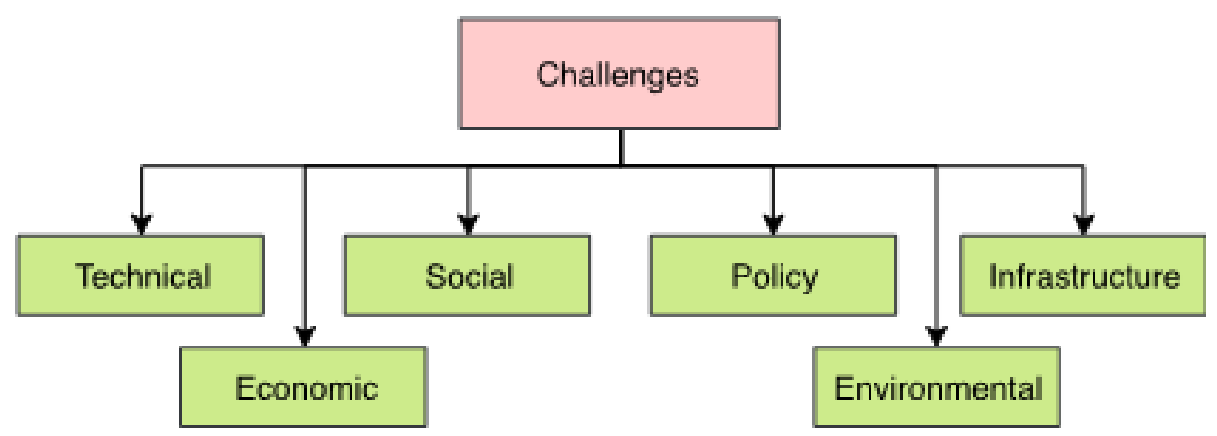

Figure 6: Electricity system transition - Challenges

\subsection{Technical Challenges Associated to the Operation of the Electricity System}

The electricity system transition signals' new challenges in the electricity system operation. The distinct technical challenges are sorted into issues relating to electricity generation arising due to the variable renewable electricity generation options, integrating this renewable into the electricity system, and most importantly to manage the load curves with the variable RES. These issues are dealt with in detail in the succeeding sections.

\subsubsection{Generation issues}

Renewable energy electricity generation provides fuel diversity but has challenges related to intermittency, variability, scalability, method of generation, i.e., centralized/decentralized, and economics $[108,109]$. Solar power and wind energy are the major renewable energy resources contributing to the additions in the installed electricity system capacity. However, these resources have inherent intermittency and variability intertwined with them as solar generates power only when there is sunshine, and wind energy generates electricity only when the wind blows. The primary renewable energy sources in the Indian electricity system are solar, wind, biomass, and small hydropower. India is a vast country with all climatic conditions in its sphere with more than 300 sunny days [110]. The climatic conditions around the country are varied, with parts of the country experiencing disparate climatic conditions (summer, monsoon, and winter) at different times. It a challenge for planning renewable generation to match the supply and demand. For instance, during the monsoon in northern India, the output from the solar will be less, which coincides with the summer in the southern part, where the output will be on the higher side.

Furthermore, during rainy seasons and at times of heavy cloud cover, the output from the solar panel is negligible. Taking all this into account for system balancing needs meticulous planning. Also, solar power goes off in the nighttime. For replacing the conventional with ground-mounted solar, a huge area is statutory. Several disquisitions argued that India has potential for more than $750 \mathrm{GW}$ of solar by using just 3\% of its wasteland [111]. But the allied aspects like grid integration and infrastructure are not considered.

India is the 4th largest wind power installations in the World [112]. Like solar, wind power also faces several issues in its generation. The output from wind power plants highly fluctuates based on the wind speed, and at times of less / no wind, wind energy will generate no power [113-115]. Biomass has its shortfalls like crop growing, environmental degradation, soil erosion, etc., and cannot be depended upon to generate large amounts of electricity $[113,114]$. Being a country with a significant population below the poverty line, there are debates in India questioning whether crops grown are for food or fuel production. Growing crops for fuel production can negatively 
affect food production and food security [116].

Hydropower is considered an important source of renewable energy electricity [117]. But the area required to build the hydropower plants, economics, resettlement issues, habitat destruction, disturbances to fisheries, and alteration of river direction makes large hydro one of the least favorable renewable options [113]. Small hydro $(<25 \mathrm{MW})$ has a huge untapped potential of about $20 \mathrm{GW}$ in the northeastern part of the country and needs massive investments to realize the potential $[23,117]$. The case with geothermal energy is that it has some known potential in Jammu \& Kashmir, other than that it is unexplored in the Indian context [119]. The issues with the variability of RES lead to the difficulty of storing the electricity, which is discussed in the next section.

\subsubsection{Renewable energy integration}

In the present electricity system contribution of renewable energy sources is low when compared to conventional electricity generation. In the future electricity system, renewable energy is expected to be a dominant player. Due to various issues discussed before, the renewable energy-dominated electricity system is challenging to manage and operate to meet the dynamic demand reliably [120]. The system faces more troubles, like system instability due to generation intermittency, injection of harmonics, DC to AC conversion losses, interoperability of devices, etc., and it is unreliable. If the system is not appropriately managed, it is prone to major outages [120] like the blackout in July-August 2012 [121]. Some issues exist, like the variability of renewable energy sources, integration cost of variable generation, storage, solar and wind forecasting, system balancing, etc., which are seen as a hindrance for its integration [122]. Fig. 7 portrays the schematic of various challenges associated with renewable integration.

The challenges can be grouped into technical (variability, storage, higher operating reserve, impact on conventional generation), weather (time-dependent availability), and economics related (cost) [123]. But the challenges are interconnected, and it is challenging to bring them under a single umbrella. In the future Indian electricity system with $40 \%$ RES, the characteristics of variability, time-dependent availability invokes critical issues in the operation of the electricity system. The primary requirements of an electricity system are system balancing, i.e., to withstand the fluctuations in electricity generation and consumption, and maintaining a stable and reliable power supply [113]. There is uncertainty in system operation because it is tough to predict the demand and even more challenging to predict the generation. With RES in the electricity system, there needs more flexibility on the supply side for effective system balancing. Renewable energy sources don't bestow this option [123]. The flexibility can be provided by additional generation capacity, i.e., operating reserve for load ramp-ups and downs and storage [124]. There is a considerable cost coupled with it. The space for storage and its maintenance poses a significant challenge [125].

The peak demand does not need to coincide with peak renewable energy generation. In the places with late evening peak demand after the sunset matching the demand and supply is a significant problem to be dealt with. Moreover, if the generation of RES is high with less demand in the daytime, conventional generation is to be ramped down [126]. The recurrent ramp up and down of conventional generators causes wear and tear to the equipment in addition to the unfavorable economics. Already, it is a sizeable challenge for the Indian electricity system. The plant load factor (PLF) of most coal power plants is hovering around $55 \%$, for which renewable energy generation is one of the logjams [29]. With the addition of $40 \%$ RES to the system, the magnanimity of this challenge increases manifolds.

Further, when compared to fossil fuel power plants, the electrical characteristics of wind and 


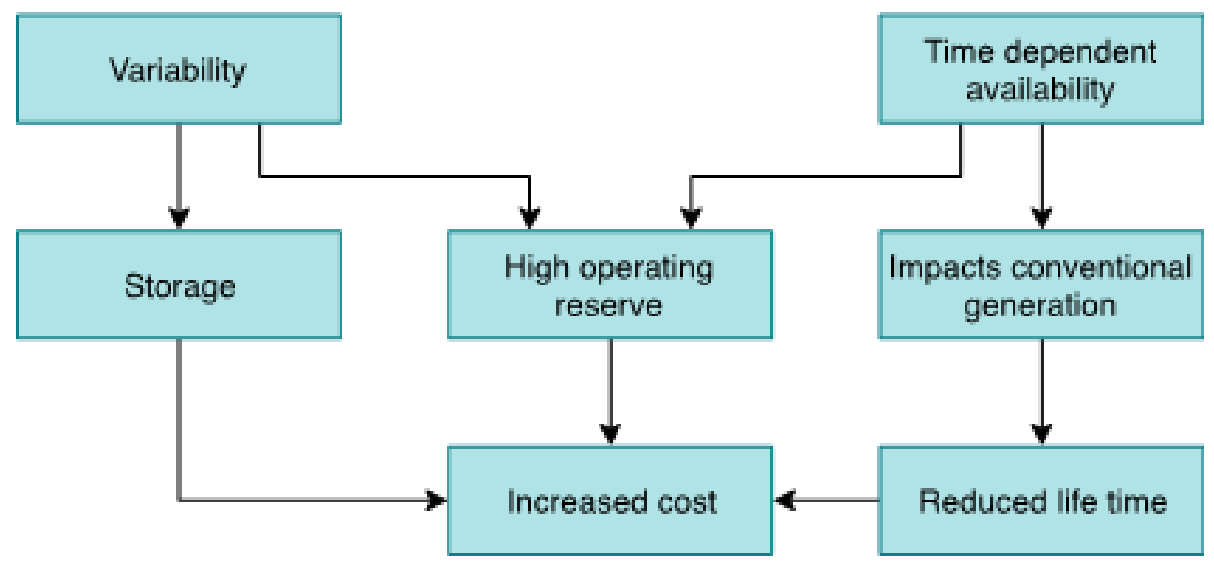

Figure 7: Schematic of renewable energy Integration challenges

solar systems are different as it employs other technology $[127,128]$. So, the system's frequency tends to fluctuate and put the function of the system in jeopardy. Because of the variability, storage comes into the picture [129]. As discussed earlier, storage is difficult to maintain and increases the system cost [129]. Advanced forecasting methods are employed to install the system with more RES to predict the generation from solar and wind power plants. Predicting the generation with renewables like solar and wind is cumbersome [130]. The cost of installing this advanced forecasting machineries substantially increases the cost of the installation, which itself a challenge for a developing country like India where the economics of the power sector is in dilapidated condition.

With the increase of RES into the system, more demand-side management (DSM) techniques will be employed for matching demand and supply [105]. DSM is an effective technique to shift the load during peak hours to non-peak hours [106]. Moreover, there is no large-scale precedence of employing these techniques in the Indian system, which needs more effort and money for its success. So, integration of renewable energy sources requires new transmission infrastructure, flexible generating resources, attractive policies from the government to incentivize renewable energy installations with subsidies, and a flexible market [18,33]. A workable demand-side management technique is also obligatory for renewable energy integration [131].

\subsubsection{Managing the load curves}

Load management (LM) is defined as "any action taken by the customer and/or the electricity supplier to change the load profile to gain from reduced total system peak load, improved utilization of valuable resources like fuels or generation, transmission and distribution capacity" [132]. The idea is to change the load profile to reduce the peak load. The two significant drawbacks of peaking are lower capacity utilization and technology constraints. Peak loads occur for a limited time, i.e., six to eight hours in a day, and during off-peak hours this capacity is redundant, resulting in low-capacity utilization.

It is difficult to manage the system transition from conventional to the one integrated with more renewable energy regarding the technology constraints. The oscillation in the solar and wind power plant output makes it difficult to manage the load curves. When a sudden dip in the RES coincides with peak hours, then managing the load curve becomes refractory. LM is strenuous when the solar power goes off in the evening around 5.30 PM. As we see from Fig. 5, this is the time the load starts increasing. With the addition of $100 \mathrm{GW}$ into the electricity system managing 
the up-surging load with $100 \mathrm{GW}$ less is a huge challenge. The expected contribution of wind power to the future electricity system portfolio is $60 \mathrm{GW}$, and the problem with wind power is the speed of wind fluctuates throughout the day. With $160 \mathrm{GW}$ of variable renewables, ensuring the stable operation of the electricity system requires some firm electricity-generating resources available to meet the demand, or the demand has to be shifted (if possible). To offset the huge deficit in supply and demand very high-capacity spinning reserve should be added to the system, which in turn has huge economic implications in the system operation.

According to National electricity policy 2005, spinning reserves are set at $5 \%$ of the peak demand and segregated into primary, secondary, and tertiary reserves [37]. With the current peak demand of $182 \mathrm{GW}$, the primary reserve amounts to $4 \mathrm{GW}$, secondary $3 \mathrm{GW}$, and the tertiary reserve stands at $2 \mathrm{GW}$. This policy was framed in the pre-renewable energy era and is not befitting to the system with a large renewable energy source capacity. An appropriate policy framework is needed to estimate the capacity of renewable energy reserves. Since the start-up time of coal, nuclear power plants (base load power plants) are high, these power plants should be operated in a spinning reserve, and when the solar goes off, this should be ramped up to meet the demand.

\subsection{Economic Issues}

Economics weighs heavily in the successful long-term operation of the system. Without an acceptable economic scheme for all the stakeholders involved, the system sets a bad precedent for future ventures. In this section, we discuss some of the financial issues expected to plague transitioning Indian electricity systems.

\subsubsection{Ill-devised subsidies}

To meet emission targets and to support the utilities in electricity generation Government of India (GOI) encourages citizens to generate renewable energy electricity through attractive policies. The initial investment for renewable installations is higher [36]. To offset this, the GOI and various state governments in the country are offering plenty of subsidies to install renewable energy capacity and its subsequent operation [118]. For example, a solar water pumping scheme was launched to support the farmers where $30 \%$ of the solar panel cost is subsidized [132]. However, providing subsidies incur a substantial financial burden on the government exchequer. It is difficult to envisage the length of the time subsidy can be provided for renewable installations. It is also difficult to predict if the obsession with renewable energy will continue once the subsidies are stopped? Many of the electricity utilities in the country are incurring heavy financial losses [69]. In the financial year 2019, the total loss of discoms is about INR 280,000 million. Moreover, as of April 2020, the total outstanding amount owed by discoms to generators is about INR 107,850.3 million. Except for the states of Bihar, Tripura, and Nagaland financial status of the majority of discoms is very bad. In the last twelve months, the overdue amount was always around INR 90,000 million [134].

Ensuring free electricity to consumers is considered a welfare measure by state governments in India [135]. In most states in India, electricity for irrigation is supplied free of cost. In 2014-15 the average revenue realized per $\mathrm{kWh}$ sold to irrigation consumers was INR $1.88 / \mathrm{kWh}$, while the average cost of supply was INR 5.2/ kWh [21]. At the end of the 2006-07 financial year, the total pump sets energized in India was 15.5 million, and it increased to 21.2 million in 2016-17 [21]. With pump sets, energization is on the increasing side. Providing free electricity in the long-term is not a viable option for the governments. Electricity is also supplied free of cost to domestic consumers by certain state governments. For example, Tamil Nadu (a state in southern India) supplies 100 
$\mathrm{kWh}$ of free electricity bimonthly to all consumers in the state. The total subsidy paid by them for the electricity sector in the year 2019-20 was INR 80,500 million [136], which is equivalent to $0.43 \%$ of gross state domestic product (calculated using data from the ministry of statistics and program implementation) [137]. Similarly, several states have their subsidy mechanism, which inflicts heavy loss to the state exchequer.

\subsubsection{Costs associated with renewable energy system installation \& operation}

The start-up costs of renewable energy systems have reduced considerably in recent years. The start-up cost of coal, large hydro, and nuclear power plants are INR 76, INR 117, and INR 190 million/MW, respectively. In contrast, the corresponding cost of solar photovoltaic, wind, and biomass plants is INR 45, INR 60, and INR 57 million/MW [26]. Renewable energy sources seem an exciting option for investments. In the case of grid-connected systems, the stakeholders can be investors, and in the case of the off-grid, it is commoner's [138]. Investors expect the return of investment quickly, and there should be a schematic available for investments in the renewable sector. The delay or blockages in any project is expected to have huge ramifications in the quest for India's $445 \mathrm{GW}$ renewable energy target [139]. In the case of commoner's rooftop systems mostly have sole ownership. In the case of community-supported off-grid systems, there should be a practical guideline towards costs of installation and benefit-sharing [140]. The system's operational costs have a marginal role to play in the economics of system operation. Compared to conventional sources, renewable energy sources' operation and maintenance costs are much lower. The fixed O \& M cost of coal, large hydro, and nuclear plants is INR 1.8, INR 3, and INR 2 million/MW. The corresponding cost of solar PV, wind, and biomass are INR 0.55, INR 0.6, and INR 1.4 million/MW [26].

The cost involved with the addition of an idle generation unit, i.e., the spinning reserve, is a significant factor to be accounted for in the functioning of the transitioning electricity system. Coal, large hydro, is part of the spinning reserve. With a nine GW spinning reserve, the cost attached to it is enormous. With the addition of more renewable energy capacity, the amount of spinning reserve is expected to increase significantly. However, having a substantial idle generating unit is not economically feasible for the system's long-term operation. Storage also plays an essential role in system operation. The cost of the battery installation and the associated maintenance swells the operation and the maintenance costs of the system [141]. This is considered one of the critical constraints in the off-grid system installation. The financial model aggregating the necessary actors responsible for bearing the system's maintenance should be enacted. Presently there is no subsidy available for the installation of batteries. In the policy direction facilitating subsidy is expected to be a problem aggravator rather than dispensing a solution [102].

\subsection{Social Issues}

Citizens are the prominent participants in the system operation. For any stratagem to succeed, the schema for social issues needs to be laid upon satisfactorily [141]. With the addition of distributed RES, the social acceptance with involved parties between parties need to be addressed genuinely. The compensation terms, if any, for land acquisition and proper resettlement issues, etc., are to be dictated appropriately [142]. In the case of India, many projects hit a roadblock because of these reasons, and one example is Narmada river hydroelectric cum water irrigation project started in 1961 and completed only in 2017 [143-145]. The major issues are people's displacement without a satisfactory compensation mechanism, as through the course of this project, nearly 400,000 people are displaced, and livelihoods of a further 600,000 are seriously affected [146]. 
People's attitude towards renewable energy is a complex subject [147]. In villages, people may feel uncomfortable having solar parks or wind farms in their vicinity without appropriate incentives for them. Educating local people, ensuring jobs, improving life standards (job opportunities), better infrastructure (roads, transport services) is an inclusive way to address the social issues. Community renewable energy installation is an arduous task [148] as people may not desire to install the system in their backyards to supply power to the neighborhoods. Theft is also a significant issue that requires special attention in these projects.

\subsection{Policy Challenges}

Policies play a vital role in the development of specific new concepts. The electricity policies are focused on assuring security, reliability, and affordability.

\subsubsection{Energy security}

The International Energy Agency (IEA) defines energy security as "the uninterrupted availability of energy sources at an affordable price" [149]. Electricity security is the highest priority for countries as it is the basis for living and social development [150]. The short-term security deals with electricity systems' ability to respond to sudden changes in demand and supply, and longterm security focus on foreseeing future electricity needs concerning environment, economic and social context and systematically adding new generating resources [151]. India's present situation is that the coal sector is plagued by problems related to underutilization, emission reduction challenges, etc. Also, a substantial part of coal for power generation is imported, which increases the cost. Oil generation also depends on imports [33], and oil price is too volatile. For nuclear power generation, India depends on other countries for importing uranium [63]. So instead of contributing to energy security, all these resources are providing energy insecurity in the long run. For achieving long-term energy security, India is placing its trust in intermittent renewable energy sources. In a renewable energy-dominated system, short-term electricity security is under severe threat due to the variable nature of energy sources. So a mix of conventional and renewable energy sources will address both short-and long-term energy security of India. Though renewable energy sources have issues related to uncertainty, variability, and intermittency, the significant advantage is free from price fluctuations. The policy focus is dedicated majorly to renewable installations, but coal will be the majority of the Indian electricity mix, albeit with a decreased percentage soon.

\subsubsection{Energy reliability \& affordability}

In some instances, in the Indian context, reliability and affordability are interlinked. Though a $100 \%$ electrification rate has been reached, sustained efforts have always been undertaken to achieve 24/7 reliable and uninterrupted electricity supply, and India is still in the process of realizing it. As of 2020, on average, the urban and rural areas in the country receive 22 and 20 hours of electricity supply, respectively [43]. This is a significant improvement considering the high energy and peak demand deficit of $10.1 \%$ and 12.7 , respectively, a decade ago. However, the number of hours of electricity supply differs from sector to sector. The electricity supply to specific sectors (irrigation \& domestic BPL consumers) is limited due to a lack of revenue realization. In many states, electricity supply to the irrigation sector is restricted to a certain number of hours. In December 2020, in Punjab irrigation sector received electricity only for 4.51 hours/day whereas, in south Indian state Karnataka, the supply of electricity for irrigation purposes is limited only to seven hours/day, where the irrigation sector accounts for $40 \%$ of total annual electricity consumption [21]. The main reason being electricity is supplied free of cost for 
irrigation purposes. Also, to reduce overuse and wastage, continuous access is restricted. Utilities do not favor continuous electricity supply to BPL consumers since the tariff of those consumers is well below the cost of supply [152]. On the consumer side, the cost barrier is the primary reason for the lack of electricity uptake [153]. The government of India is providing free metered connections to BPL families, but still, consumers are not availing it due to the financial incapability to pay the monthly bills $[43,153]$. Tariff subsidy is essential to include low-income families in the electricity consumption chain. However, the distribution companies are already making huge losses. In this context, increasing the subsidy to the poor is another major challenge faced by the utilities in addition to free electricity to agriculture. Extending free electricity supply only to needy farmers and increasing the subsidy to BPL families are necessary interventions essential to reach $24 / 7$ reliable and affordable electricity supply. All farmers are enjoying free electricity for decades. Suddenly limiting to certain sects will be a considerable policy challenge as it may adversely affect the ruling party's electoral prospects.

\subsection{Infrastructure Challenges}

To balance intermittent renewable energy generation, demand fluctuations, and grid flexibility, storage is considered an essential part of the electricity system. During 2019 and 2025, India's cumulative potential for energy storage is estimated as $190 \mathrm{GWh}$ [154]. Pumped storage hydro (PSH) and battery storage are the central storage technologies focused on by the government of India $[155,156]$. As of 2020, only $3.3 \mathrm{GW}$ of PSH is under working condition, and a further 1.5 GW is under construction [157,158]. Construction of close to 4 GW PSH capacity is held up due to technical and policy, and financial reasons [157]. The capital expenditure required to install $1 \mathrm{MW}$ of PSH is INR 128.7 million. In contrast, the capital expenditure for $1 \mathrm{MW}$ coal, solar, and wind power plant is INR 76, INR 45, and INR 60 million, respectively [26]. PSH installation requires high capital investments but, the potential available is over $96.5 \mathrm{GW}$ [154]. In India, battery storage projects have been small and limited. As per the central electricity authority (CEA) study, India needs a grid-connected battery storage capacity of $34 \mathrm{GW}$ producing $136 \mathrm{GWh}$ by 2030 [26]. Still, the expected market for grid-connected battery storage is only $62 \mathrm{GWh}$ by 2027 [158]. To promote electric vehicles and battery storage, India has set out a national mission on transformative mobility and battery storage in 2019 to become one of the leading battery manufacturers in the World $[153,158]$. With 445 GW of planned renewable energy capacity by 2030, there is a high requirement for corresponding storage additions. The current progress in this sector is so far limited to a few GW's. Improving the situation requires vast investments, development of $R \& D$ centers, and appropriate policies. In the transmission sector, the study to ensure network adequacy for achieving the $445 \mathrm{GW}$ renewable energy target is so far not explored [158].

In manufacturing, the number of homegrown solar manufacturers is fewer, which forced the project planners to import the solar modules [159]. According to domestic content policy, the Ministry of New and Renewable Energy (MNRE) has mandated using a certain amount of locally manufactured components in solar photovoltaic installations [160]. The majority of imports are from China, and Indian manufacturers could not compete with them, especially with cost. The generated renewable energy electricity needs to be converted from $\mathrm{DC}$ to $\mathrm{AC}$, and it requires a massive number of inverters. So there requires extensive investments and policy clarity in the entire renewable energy supply chain.

There is not enough done on the manufacturing sector [161]. The policy thrust given to the renewable installations is missing from manufacturing base development. If the government is serious about this, more incentives are a prerequisite, at least in the initial stages of the industry development. Moreover, depending on imports for renewable energy installations is also a case for 
high energy insecurity. In the changing global political landscape, especially with the recent India China conflict, self-sufficiency is an essential requirement for maintaining the country's energy security at the infrastructural level.

\subsection{Environmental Challenges}

Although the transition towards renewable energy is expected to positively contribute towards reducing emissions from the electricity sector, it also has some undesirable effects on the environment [162]. The land-use change is one of the significant issues with renewable energy installations since the area engaged can be used for some other purposes. India is the second most populated country in the World. However, its land area is just $2.3 \%$ of the World's total landmass. Loss of biodiversity (forest, landscapes, hills, etc.) is another major issue that needs to be addressed as India houses numerous indigenous tribes living in forests and hills. Due to this issue obtaining clearance for renewable energy projects could be a bottleneck as it may affect their unique lifestyles.

Moreover, cleaning solar panels requires a large amount of water which may be problematic in water-constrained locations [163]. Especially between the south Indian states of Karnataka and Tamil Nadu, the water conflict is severe during the summer months. In South India, many of the rivers are non-perennial, and if the monsoon is below average, water scarcity is too challenging to handle. Also, groundwater is depleting at a faster rate, and caution is essential during the planning phase of the projects $[164,165]$. The end-of-life status of components has not been appropriately discussed since the major power plants did not reach that stage.

In the case of wind power plants, the rotation of the rotor is fatal to birds. The noise coming out of the wind power plant makes a living in the locality impossible [166]. India is the place with World's largest cattle population [167]. There will be cattle in all the locations. Reducing their grazing area for installations will hamper their free movement and creates possible food scarcity for animals. Sea navigation is an integral part of India's import and export as three sides of India are surrounded by water. Gujarat and Tamil Nadu coasts are identified as potential offshore wind locations, and it is seen as a hindrance to shipping movement near the coastline [168]. These two places are critical for India's maritime security as people illegally entered in the past to instigate anti-social activities. So, installations in these locations will create a possible security threat. The issues with biomass invoke a new query, whether crops are grown for generating electricity or meeting the population's basic requirements. As already discussed, in India, with $30 \%$ living below the poverty line, this is a problem of paramount importance and very strenuous to defend for the growth of the biomass sector. Most of the off-grid potential is identified in the Northeastern part of India, especially in Uttarakhand [23]. Historically this locality is prone to landslides, and small hydro installation in those regions may aggravate the existing danger [169]. Moreover, it is considered a holy place by most of the country's population. Installing small hydro in those locations may create unease among the people and tourists. It will also adversely impact the marine ecosystem.

\section{CONCLUSION}

From 1947 to 2010, around 168 GW of installed capacity has added to the electricity system, and between 2010 and 2020 alone, the capacity added is 207 GW. Indian electricity system experienced a growth rate of $121 \%$ in the last decade [22], and the present installed capacity is expected to more than double by 2030. Generating electricity through renewable energy sources has become a norm rather than optional. India targets $40 \%$ of installed capacity from renewable energy sources by 2030 . 
So, India is transitioning from a fossil fuel monopolized electricity system to significant renewable energy contributed electricity system. The transitioning system faces enormous challenges at the generation, transmission, and distribution levels. The generation level challenges extend from new generation technologies and the linked technical constraints. This drives the system towards addressing the next level of challenges that emerged from the generation, i.e., transmission \& distribution phase. The new generation sources tend to threaten grid reliability and flexibility. Above transitions usher a new era in the demand side systems where the consumption changes of consumers take prominence. To effectively tackle these transitions, the government policies are guiding at various levels of the electricity system. Since RES is gaining significance in the system, the inherent challenges entail attention. For instance, revisiting the electricity subsidies, ensuring energy security and affordability, policies to address infrastructure challenges, and a framework to deal with environmental issues, to name a few. With the global carbon emission scenario and India's ever-growing energy need, the transition is inevitable, and the challenges emerging out of these transitions are inexorable. Having achieved 100\% electrification in 2018, the goalposts have been shifted to reliable and low carbon electricity supply. The requirement is inclusive policy direction entailing policymakers, project developers, investors, and most importantly, citizens to cater to the foreseen and unforeseen challenges of the electricity system transition. The electricity system transition is eternal, i.e., in the future, more renewable energy will be added to the system, and the supposition from these systems is, it can provide uninterrupted reliable and less carbon electricity.

\section{Declaration of interest: None}

\section{REFERENCES}

[1] Atems B, Hotaling C. The effect of renewable and non-renewable electricity generation on economic growth. Energy Policy 2018:112:111-118.

[2] McKenna E, Richardson I, Thomson M. Smart meter data: Balancing consumer privacy concerns with legitimate applications. Energy Policy 2012:41:807-814.

[3] World Bank. Tracking SDG7: The Energy Progress Report. 2018.

[4] IEA. World Energy Outlook - 2016. 2016.

[5] BP. BP Statistical Review of World Energy. 2018.

[6] Marques AC, Fuinhas JA, Pereira DA. Have fossil fuels been substituted by renewables? An empirical assessment for 10 European countries. Energy Policy 2018:116:257-265.

[7] Liu X, Du H, Brown MA, Zuo J, Zhang N, Rong Q, et al. Low-carbon technology diffusion in the decarbonization of the power sector: Policy implications. Energy Policy 2018:116:344-356.

[8] Kilickaplan A, Bogdanov D, Peker O, Caldera U, Aghahosseini A, Breyer C. An energy transition pathway for Turkey to achieve $100 \%$ renewable energy powered electricity, desalination and non-energetic industrial gas demand sectors by 2050. Solar Energy 2017:158:218-235.

[9] Li FGN, Trutnevyte E. Investment appraisal of cost-optimal and near-optimal pathways for the UK electricity sector transition to 2050. Applied Energy 2017:189:89-109.

[10] Chen H, Wang C, Cai W, Wang J. Simulating the impact of investment preference on low-carbon transition in power sector. Applied Energy 2018:217:440-455.

[11] Wu Y, Zhu Q, Zhu B. Comparisons of decoupling trends of global economic growth and energy consumption between developed and developing countries. Energy Policy 2018:116:30-38. 
[12] Senshaw DA, Kim JW. Meeting conditional targets in nationally determined contributions of developing countries: Renewable energy targets and required investment of GGGI member and partner countries. Energy Policy 2018:116:433-443.

[13] Rosenbloom D, Haley B, Meadowcroft J. Critical choices and the politics of decarbonization pathways: Exploring branching points surrounding low-carbon transitions in Canadian electricity systems. Energy Research $\mathcal{E}$ Social Science 2018:37:22-36.

[14] Bell K, Gill S. Delivering a highly distributed electricity system: technical, regulatory and policy challenges. Energy Policy 2018:113:765-777.

[15] Wu KY, Huang $\mathrm{YH}, \mathrm{Wu} \mathrm{JH}$. Impact of electricity shortages during energy transitions in Taiwan. Energy 2018:151:622-632.

[16] Mori A. Temporal dynamics of infrasystem transition: The case of electricity system transition in Japan. Technological Forecasting and Social Change 2019:145:186-194.

[17] Sovacool BK, Kester J, de Rubens GZ, Noel L. Expert perceptions of low-carbon transitions: Investigating the challenges of electricity decarbonisation in the Nordic region. Energy 2018:148:1162-1172.

[18] Shrimali G, Trivedi S, Srinivasan S, Goel S, Nelson D. Cost-effective policies for reaching India's 2022 renewable targets. Renewable Energy 2016:93:255-268.

[19] Mittal S, Dai H, Fujimori S, Masui T. Bridging greenhouse gas emissions and renewable energy deployment target: Comparative assessment of China and India. Applied Energy 2016:166:301-313.

[20] Singh R. Energy sufficiency aspirations of India and the role of renewable resources: Scenarios for future. Renewable and Sustainable Energy Reviews 2018:81:2783-2795.

[21] Government of India Ministry of Power. Executive Summary on Power Sector December-2020. 2020.

[22] Government of India Ministry of Power. Power Sector at a glance All India 2020. https:/ / powermin.nic.in/en/content/power-sector-glance-all-india (accessed May 20, 2020).

[23] Central Electricity Authority. Installed Capacity Reports. 2017. http:/ / www.cea.nic.in/reports.html (accessed December 28, 2017).

[24] Mishra MK, Khare N, Agrawal AB. Small hydro power in India: Current status and future perspectives. Renewable and Sustainable Energy Reviews 2015:51:101-115.

[25] Singh A. Power sector reform in India: current issues and prospects. Energy Policy 2006:34:2480-2490.

[26] GOI. Ministry of Power. 2017.

[27] GOI Ministry of Power. Report on Optimal Generation Capacity Mix for 2029-30. 2020.

[28] Sahoo NR, Mohapatra PKJ, Mahanty B. Examining the process of normalising the energy-efficiency targets for coal-based thermal power sector in India. Renewable and Sustainable Energy Reviews 2018:81:342-352.

[29] MNRE. Ministry of New and Renewable Energy 2018. https://mnre.gov.in/.

[30] GOI. Report of the Expert Group on 175 GW RE by 2022. 2015.

[31] Simshauser P. On intermittent renewable generation and; the stability of Australia's National Electricity Market. Energy Economics 2018:72:1-19.

[32] $\mathrm{Hu}$ J, Harmsen R, Crijns-Graus W, Worrell E. Barriers to investment in utility-scale variable renewable electricity (VRE) generation projects. Renewable Energy 2018:121:730-744.

[33] Farooquee AA, Shrimali G. Making renewable energy competitive in India: Reducing financing costs via a government-sponsored hedging facility. Energy Policy 2016:95:518-528.

[34] Batalla-Bejerano J, Trujillo-Baute E. Impacts of intermittent renewable generation on electricity system costs. Energy Policy 2016:94:411-420.

[35] GOI. Growth of Electricity Sector in India from 1947-2017. 2018. 
[36] Chandel SS, Shrivastva R, Sharma V, Ramasamy P. Overview of the initiatives in renewable energy sector under the national action plan on climate change in India. Renewable and Sustainable Energy Reviews 2016:54:866-873.

[37] MOP. Ministry of Power 2018. https://powermin.nic.in/en/content/national-electricitypolicy (accessed March 31, 2018).

[38] Government of India. Executive Summary. 2018.

[39] Riva F, Ahlborg H, Hartvigsson E, Pachauri S, Colombo E. Electricity access and rural development: Review of complex socio-economic dynamics and causal diagrams for more appropriate energy modelling. Energy for Sustainable Development 2018:43:203-323.

[40] Winther T, Ulsrud K, Saini A. Solar powered electricity access: Implications for women's empowerment in rural Kenya. Energy Research \& Social Science 2018:44:61-74.

[41] GOI. Saubhagya. 2018. http://saubhagya.gov.in/ (accessed January 17, 2019).

[42] Bali N, Vermani S, Mishra V. Electricity Access in India Benchmarking Distribution Utilities. 2020.

[43] Agrawal S;, Mani S, Jain A, Ganesan K; Insights from the India Residential Energy Survey (IRES 2020). 2020.

[44] International Energy Agency. Energy Access Outlook 2017. 2017.

[45] Balachandra P. Dynamics of rural energy access in India: An assessment. Energy 2011:36:5556-5567.

[46] Nouni MR, Mullick SC, Kandpal TC. Providing electricity access to remote areas in India: Niche areas for decentralized electricity supply. Renewable Energy 2009:34:430-434.

[47] Palit D, Bandyopadhyay KR. Rural electricity access in India in retrospect: A critical rumination. Energy Policy 2017:109:109-120.

[48] Olivier, Jos GJ, Janssens-Maenhout G, Muntean M, Marilena; Peters J. Trends in Global CO2 Emissions: 2014 Report. 2014.

[49] World Bank. CO2 emissions (metric tons per capita). http://data.worldbank.org/indicator/ EN.ATM.CO2E.PC?page $=1$

[50] BP. BP Statistical Review of World Energy. 2020.

[51] IEA. Global Energy \& CO2 Status Report 2019. 2019.

[52] Tracker CAc. CAT warming projections - global update 20172018. http://climateactiontracker.org/countries/india/current-policy-projections/ (accessed April 28, 2018).

[53] GoI. CO2 Baseline Database for the Indian Power Sector User Guide. 2011.

[54] Ministry of Power Government of India. CO2 Baseline Database for the Indian Power Sector. 2019.

[55] GOI. Draft National Energy Policy. 2017.

[56] Shrimali G. Managing power system flexibility in India via coal plants. Energy Policy 2021:150:112061.

[57] Ministry of Environment and Forests. India's Intended Nationally Determined Contribution is Balanced and Comprehensive: Environment Minister. 2015.

[58] Bandyopadhyay S. Renewable targets for India. Clean Technologies and Environmental Policy 2017:19:293-294.

[59] Rahmani M, Jaramillo P, Hug G. Implications of environmental regulation and coal plant retirements in systems with large scale penetration of wind power. Energy Policy 2016:95:196-210.

[60] Ryan N. The Competitive Effects of Transmission Infrastructure in the Indian Electricity Market. 2017.

[61] Gandotra V. IIT Delhi: Introduction to Smart Grids. 2011.

[62] Li F, Qiao W, Sun H, Wan H, Wang J, Xia Y, et al. Smart transmission grid: Vision and framework. IEEE Trans Smart Grid 2010:1:168-177. 
[63] EIA. India aims to reduce high electricity transmission and distribution system losses 2015. https://www.eia.gov/todayinenergy/detail.php?id=23452 (accessed April 28, 2018).

[64] Ministry of Power GOI. National power portal 2020. https://npp.gov.in/glossary (accessed March 6, 2021).

[65] Ministry of Power GOI. Losses of Electricity Units Not Billed by States/UTs Provisionally Comes to 15.73 percent. 2020.

[66] Joseph KL. The politics of power: Electricity reform in India. Energy Policy 2010:38:503-511.

[67] Kale SS. Current reforms: The politics of policy change in India's electricity sector. Pacific Affairs 2004:77:467-491.

[68] Bhattacharyya SC. The Electricity Act 2003: will it transform the Indian power sector? Utilities Policy 2005:13:260-272.

[69] Government Of India Ministry of Power. Ujwal Discom Assurance Yojana (UDAY). 2020.

[70] Min B, Golden M. Electoral cycles in electricity losses in India. Energy Policy 2014:65:619-625.

[71] Government Of India Ministry of Power. Minsitry of Power - Overview. 2018. https://powermin.nic.in/en/content/overvie-0\# (accessed April 4, 2018)

[72] GOI. Inter Regional Transmission Capacity - Program of National Grid Development. 2018.

[73] NHPC. National Hydroelectric Power Corporation on India 2018. http://www.nhpcindia.com/home.aspx\# (accessed April 12, 2018).

[74] NTPC. National Thermal Power Corporation on India 2018. http://www.ntpc.co.in/ (accessed April 11, 2018).

[75] GOI Ministry of Coal. Coal reserves. 2020. http://coal.nic.in/major-statistics/coal-reserves (accessed March 9, 2021).

[76] GOI Ministry of Coal. Provisional Coal Statistics. n.d.

[77] Kumar A, Kumar K, Kaushik N, Sharma S, Mishra S. Renewable energy in India: Current status and future potentials. Renewable and Sustainable Energy Reviews 2010:14:2434-2442.

[78] Höffken JI. A closer look at small hydropower projects in India: Social acceptability of two storage-based projects in Karnataka. Renewable and Sustainable Energy Reviews 2014:34:155-166.

[79] Puthiyavinayagam P, Selvaraj P, Balasubramaniyan V, Raghupathy S, Velusamy K, Devan K, et al. Development of fast breeder reactor technology in India. Progress in Nuclear Energy 2017:101:19-42.

[80] Banerjee S, Gupta HP. The evolution of the Indian nuclear power programme. Progress in Nuclear Energy 2017:101:4-18.

[81] Grover RB. Opening up of international civil nuclear cooperation with India and related developments. Progress in Nuclear Energy 2017:101:160-167.

[82] Government Of India. Central Electricity Authority 2018. http://www.cea.nic.in/index.aspx (accessed April 1, 2018).

[83] Dash DP, Sethi N, Bal DP. Is the demand for crude oil inelastic for India? Evidence from structural VAR analysis. Energy Policy 2018:118:552-528.

[84] Gambhir A, Napp TA, Emmott CJM, Anandarajah G. India's CO 2 emissions pathways to 2050: Energy system, economic and fossil fuel impacts with and without carbon permit trading. Energy 2014:77:791-801.

[85] Kumar S, Madlener R. CO2 emission reduction potential assessment using renewable energy in India. Energy 2016:97:273-282.

[86] Abbasi T, Abbasi SA. Small hydro and the environmental implications of its extensive utilization. Renewable and Sustainable Energy Reviews 2011:15:2134-2143.

[87] Guttikunda SK, Jawahar P. Atmospheric emissions and pollution from the coal-fired thermal power plants in India. Atmospheric Environment 2014:92:449-460. 
[88] Tripathi L, Mishra AK, Dubey AK, Tripathi CB, Baredar P. Renewable energy: An overview on its contribution in current energy scenario of India. Renewable and Sustainable Energy Reviews 2016:60:226-233.

[89] Garg A, Tiwari V, Vishwanathan S. Relevance of Clean Coal Technology for India's Energy Security: A Policy Perspective. IOP Conference Series: Earth and Environmental Science 2017:76:012001.

[90] Bhattacharya S, Singh AK, Choudhury A. Coal Resources, Production and use in India. The Coal Handbook: Towards Cleaner Production. Woodhead Publishing, Cambridge, 2013, p.169-199.

[91] Chikkatur A, Sagar A. Carbon mitigation in the indian coal-power sector: Options and recommendations. Energy Procedia 2009:1:3901-3907.

[92] CEA, MOP. National Electricity Plan (Volume 1) Generation. 2018.

[93] DST. Clean Coal Technologies in India: Current Status, Demands and Aspirations - Pathways to Achievements. 2016.

[94] Patil AC. Transition to Clean Coal Technologies in India. Computer Aided Chemical Engineering 2009:27:1731-1736.

[95] NPCIL. Nuclear Power Corporation of India Limited 2018. http:/ /www.npcil.nic.in/index.aspx (accessed April 11, 2018).

[96] GOI Ministry of Power. http://powermin.nic.in/power-sector-glance-all-india (accessed January 18, 2016).

[97] GOI Ministry of New and Renewable Energy Grid Connected Rooftop Solar Division. 2017.

[98] Sen S, Ganguly S, Das A, Sen J, Dey S. Renewable energy scenario in India: Opportunities and challenges. Journal of African Earth Sciences 2016:122:25-31.

[99] Sinha A, Shahbaz M. Estimation of Environmental Kuznets Curve for CO 2 emission: Role of renewable energy generation in India. Renewable Energy 2018:119:703-711.

[100] Chatterjee E. The politics of electricity reform: Evidence from West Bengal, India. World Development 2018:104:128-139.

[101] Ponce-Jara MA, Ruiz E, Gil R, Sancristóbal E, Pérez-Molina C, Castro M. Smart grid: Assessment of the past and present in developed and developing countries. Energy Strategy Reviews 2017:18:38-52.

[102] Bhattacharyya R, Ganguly A. Cross subsidy removal in electricity pricing in India. Energy Policy 2017:100:181-190.

[103] TERI. Transitions in Indian Electricity Sector 2017-2030. 2017.

[104] Balasubramanian S, Balachandra P. Characterising electricity demand through load curve clustering: A case of Karnataka electricity system in India. Computers \& Chemical Engineering 2021:150:107316.

[105] Thakur J, Chakraborty B. Demand side management in developing nations: A mitigating tool for energy imbalance and peak load management. Energy 2016:114:895-912.

[106] Group PE. Demand Side Management in India: An Overview of State Level Initiatives. 2014.

[107] Harish VSKV, Kumar A. Demand side management in India: Action plan, policies and regulations. Renewable and Sustainable Energy Reviews 2014:33:613-624.

[108] Veldhuis AJ, Leach M, Yang A. The impact of increased decentralised generation on the reliability of an existing electricity network. Applied Energy 2018:215:479-502.

[109] Khan J, Arsalan MH. Solar power technologies for sustainable electricity generation-A review. Renewable and Sustainable Energy Reviews 2016:55:414-425.

[110] Arjunan TV., Aybar HŞ., Nedunchezhian N. Status of solar desalination in India. Renewable and Sustainable Energy Reviews 2009:13:2408-2418. 
[111] PIB. India takes giant leap on Green Energy Targets. 2017. http:/ / pib.nic.in/newsite/printrelease.aspx?relid=161622 (accessed April 29, 2018).

[112] PTI. India Ranks 4th Globally in Wind Power Installation: Survey. 2017.

[113] Behboodi S, Chassin DP, Crawford C, Djilali N. Renewable resources portfolio optimization in the presence of demand response. Applied Energy 2016:162:139-148.

[114] Stram BN. Key challenges to expanding renewable energy. Energy Policy 2016:96:728-734.

[115] Aghaei J, Alizadeh M-I. Demand response in smart electricity grids equipped with renewable energy sources: A review. Renewable and Sustainable Energy Review 2013:18:64-72.

[116] Popp J, Lakner Z, Harangi-Rákos M, Fári M. The effect of bioenergy expansion: Food, energy, and environment. Renewable and Sustainable Energy Reviews 2014:32:559-578.

[117] Chattopadhyay D. Modelling renewable energy impact on the electricity market in India. Renewable and Sustainable Energy Reviews 2014:31:9-22.

[118] Routledge P. Voices of the dammed: discursive resistance amidst erasure in the Narmada Valley, India. Political Geography 2003:22:243-270.

[119] GOI. Ministry of New and Renewable Energy 2016. http://mnre.gov.in/schemes/gridconnected/small-hydro/ (accessed February 25, 2016).

[120] Sharma, OUMP, Trikha P. Geothermal Energy and Its Potential in India. 2013.

[121] Zehir MA, Batman A, Bagriyanik M. Review and comparison of demand response options for more effective use of renewable energy at consumer level. Renewable and Sustainable Energy Reviews 2016:56:631-642.

[122] POSOCO. Report of the Enquiry Committee on Grid Disturbance in Northern Region. 2012.

[123] National Renewable Energy Laboratory. Wind Maps 2016. http:/ /www.nrel.gov/gis/data_wind.html (accessed May 29, 2016).

[124] Bird L, Milligan M, Lew D. Integrating Variable Renewable Energy: Challenges and Solutions. 2013.

[125] Mwasilu F, Justo JJ, Kim EK, Do TD, Jung JW. Electric vehicles and smart grid interaction: A review on vehicle to grid and renewable energy sources integration. Renewable and Sustainable Energy Reviews 2014:34:501-516.

[126] Castillo A, Gayme DF. Grid-scale energy storage applications in renewable energy integration: A survey. Energy Conversion and Management 2014:87:885-894.

[127] Shahmohammadi A, Sioshansi R, Conejo AJ, Afsharnia S. The role of energy storage in mitigating ramping inefficiencies caused by variable renewable generation. Energy Conversion and Management 2018:162:307-320.

[128] Katiraei F, Aguero JR. Solar PV integration challenges. IEEE Power and Energy Magazine 2011:9:62-71.

[129] Xie L, Carvalho PMS, Ferreira L a FM, Juhua Liu, Krogh BH, Popli N, et al. Wind integration in power systems: Operational challenges and possible solutions. Proceedings of the IEEE 2011:99:214-232.

[130] Speidel S, Bräunl T. Leaving the grid-The effect of combining home energy storage with renewable energy generation. Renewable and Sustainable Energy Reviews 2016:60:121-124.

[131] Balasubramanian S, Balachandra P. Effectiveness of demand response in achieving supply-demand matching in a renewables dominated electricity system: A modelling approach. Renewable and Sustainable Energy Reviews 2021:147:111245.

[132] Chaiamarit K, Nuchprayoon S. Impact assessment of renewable generation on electricity demand characteristics. Renewable and Sustainable Energy Reviews 2014:39:995-1004.

[133] Grattieri W. Electric Load Management in Industry. 2009.

[134] NABARD. 2016. https://www.nabard.org/english/installation_of_solar.aspx (accessed May 30, 2016). 
[135] Government Of India Ministry of Power. Payment Ratification And Analysis in Power Procurement for Bringing Transparency in Invoicing of generators. 2020.

[136] Kato A, Fukumi A. Political economy of agricultural electricity tariffs: Rural politics of Indian States. Energy Policy 2020:145:111755.

[137] Government of Tamil Nadu. Tamil Nadu Electricity Regulatory Commission. 2019.

[138] Government of India. MOSPI Gross State Domestic Product. 2020.

[139] SECI. Solar Energy corporation of India Limited 2018. http://www.seci.gov.in/content/innerpage/off-grid-pv.php (accessed February 9, 2018).

[140] Hairat MK, Ghosh S. 100GW solar power in India by 2022-A critical review. Renewable and Sustainable Energy Reviews 2017:73:1041-1050.

[141] PTI. Sluggish Rooftop Solar Scheme Spurs Government to Work on New Plan. 2018.

[142] Aklin M, Cheng C-Y, Urpelainen J. Social acceptance of new energy technology in developing countries: A framing experiment in rural India. Energy Policy 2018:113:466-477.

[143] Jeslin Drusila Nesamalar J, Venkatesh P, Charles Raja S. The drive of renewable energy in Tamilnadu: Status, barriers and future prospect. Renewable and Sustainable Energy Reviews 2017:73:115-124.

[144] Chapamn J. India's Narmada dams controversy. The Journal of International Communication 2007:13:71-85.

[145] Turaga U. Damming waters and wisdom: protest in the Narmada River Valley. Technology in Society 2000:22:237-253.

[146] Routledge P. Voices of the dammed: discursive resistance amidst erasure in the Narmada Valley, India. Political Geography 2003:22:243-270.

[147] Luthra S, Kumar S, Garg D, Haleem A. Barriers to renewable/sustainable energy technologies adoption: Indian perspective. Renewable and Sustainable Energy Reviews 2015:41:762-776.

[148] Ramchandran N, Pai R, Parihar AKS. Feasibility assessment of Anchor-Business-Community model for off-grid rural electrification in India. Renewable Energy 2016:97:197-209.

[149] International Energy Agency. Statistics (Ber) 2011. www.iea.org (accessed March 8, 2016).

[150] Partridge I. Renewable electricity generation in India-A learning rate analysis. Energy Policy 2013:60:906-915.

[151] Kisel E, Hamburg A, Härm M, Leppiman A, Ots M. Concept for energy security matrix. Energy Policy 2016:95:1-9.

[152] Phadke A, Park WY, Abhyankar N. Providing reliable and financially sustainable electricity access in India using super-efficient appliances. Energy Policy 2019:132:1163-1175.

[153] Sankhyayan P, Dasgupta S. 'Availability' and/or 'Affordability':What matters in household energy access in India? Energy Policy 2019:131:131-143.

[154] India Smart Grid Forum. Energy Storage System Roadmap for India: 2019-2032. 2019.

[155] Shyam B, Kanakasabapathy P. Large scale electrical energy storage systems in India- current status and future prospects. Journal of Energy Storage 2018:18:112-120.

[156] Sivakumar N, Das D, Padhy NP, Senthil Kumar AR, Bisoyi N. Status of pumped hydro-storage schemes and its future in India. Renewable and Sustainable Energy Reviews 2013:19:208-213.

[157] Government of India Ministry of Power. Pumped Storage Hydro. 2021.

[158] IEA. India 2020 Energy Policy Review. 2020.

[159] Moallemi EA, Aye L, Webb JM, de Haan FJ, George BA. India's on-grid solar power development: Historical transitions, present status and future driving forces. Renewable and Sustainable Energy Reviews 2017:69:239-247.

[160] MNRE. National Solar Mission. 2016. 
[161] Rathore PKS, Rathore S, Pratap Singh R, Agnihotri S. Solar power utility sector in india: Challenges and opportunities. Renewable and Sustainable Energy Reviews 2017:81:2703-2713.

[162] Akella AK, Saini RP, Sharma MP. Social, economical and environmental impacts of renewable energy systems. Renewable Energy 2009:34:390-396.

[163] Tsoutsos T, Frantzeskaki N, Gekas V. Environmental impacts from the solar energy technologies. Energy Policy 2005:33:289-296.

[164] Abijith D, Saravanan S, Singh L, Jennifer JJ, Saranya T, Parthasarathy KSS. GIS-based multi-criteria analysis for identification of potential groundwater recharge zones - a case study from Ponnaniyaru watershed, Tamil Nadu, India. HydroResearch 2020:3:1-14.

[165] Jain M, Fishman R, Mondal P, Galford GL, Bhattarai N, Naeem S, et al. Groundwater depletion will reduce cropping intensity in India. Science Advances 2021:7:eabd2849.

[166] Wolsink M. Wind power implementation: The nature of public attitudes: Equity and fairness instead of "backyard motives." Renewable and Sustainable Energy Reviews 2007:11:1188-1207.

[167] Zerrahn A. Wind Power and Externalities. Ecological Economics 2017:141:245-260.

[168] Haggett C. Understanding public responses to offshore wind power. Energy Policy 2011:39:503-510.

[169] Juyal N, Pant RK, Basavaiah N, Bhushan R, Jain M, Saini NK, et al. Reconstruction of Last Glacial to early Holocene monsoon variability from relict lake sediments of the Higher Central Himalaya, Uttrakhand, India. Journal of Asian Earth Sciences 2009:34:437-449.

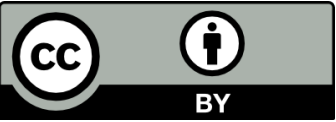

(C) The Author(s) 2022. This article is published under a Creative Commons Attribution (CC-BY) 4.0 International License. 